\title{
超臨界流体によるクロマトグラフィー分離
}

Supercritical Fluid Chromatographic Separation

山本 修一

Yamamoto, Shuichi

The relationships between the plate height HETP and the linear mobile phase velocity $u$ in supercritical fluid chromatography (SFC) were investigated over a wide range of experimental conditions (pressure $p=8.5 \sim 15 \mathrm{MPa}$, temperature $T=35 \sim 45^{\circ} \mathrm{C}$ ) with carbon dioxide as the mobile phase. When the HETP - $u$ curves were converted into the dimensionless variables $h=H E T P / d_{p}$ and $\nu=u d_{p} / D_{m}$, the curves were similar regardless of the pressure, the temperature and the state of the mobile phase. The distribution coefficient $K$ decreased with increasing $T$ and/or $p$. The $K$ values were correlated to the mobile phase density. A linear increase of the pressure was applied to elute the sample from the column. The result was simulated by a chromatography model with the isobar chromatography data. These results have shown that the separation behavior of SFC at low sample loadings can be predicted by ordinary liquid chromatography models. Further research should be done for the prediction of the separation behavior at overloaded conditions.

[supercritical fluid, chromatography, diffusion coefficient, axial dispersion, HETP, distribution coefficient]

1. はじめに

クロマトグラフィーは移動速度差分離法と定義され る高度分離手法であり $1 \mathrm{~mL}$ 以下のカラムによる微量 分析から数 $100 \mathrm{~L}$ カラムによる大量 (工業) 分離プロ セスまで多様な利用が可能である。

クロマトグラフィーカラムは移動相と固定相の 2 相 により構成されており、固定相の性質を変えることに より種々の分離原理（溶質一固定相の相互作用）が利 用できる。一方、移動相についても液相を利用する液 体クロマトグラフィー (LC)、気相によるガスクロマ トグラフィー (GC) があるが、分取にはほとんど LC が使用されている。後述するように、LCの分離性能は 固定相内部での㹡散速度により支配されているので、 精密分離あるいは高生産性が必要とされるときには、 拡散速度を向上する工夫が必要となる。

超臨界流体を移動相として使用するクロマトグラ フィー（ SFC）は超臨界流体の特徵である高拡散性 のため LC を越える分離性能が期待できると考えられ ている [2-6]。工業プロセスとしての LC 操作におけ る重要な設計基準である生産性は、種々の操作条件お よびカラム条件の複雑な関数である $[1,8,11,12]$ 。圧 力 $(p)$ と温度 $(T)$ が非常に重要な操作変数となる SFC の生産性は LC に比較して、さらに複雑な関数と
なる。

また厳密に LC と SFC の分離性能あるいは生産性 を比較した研究は非常に少なく、SFCの利点・欠点あ るいは適用可能範囲なども明確にされていない。

筆者は、主として高分子を対象とした LC の最適分 取条件推算方法を検討してきた $[7-9,11,12]$ 。この方 法に基ついて超臨界流体系と液系の両方について広範 な実験条件下での実験結果を解析した。特に超臨界流 体と通常の液体移動相との違いを明確にするために力 ラム内物質移動特性 (HETPと移動相線速度の関係) と固定相一移動相間の分配係数について詳細に検討し た $[13,15]$ 。本稿では、これらの結果に基づいて SFC 分離プロセスについて概説する。

\section{2. クロマトグラフィー分離性能の解析}

ふつうクロマトグラフィーは円筒状カラムに固定 相粒子を充填したカラムにより回分式に操作される。 もっとも単純な操作法は、移動相に溶解した試料をバ ルブにより少量注入し一定移動相で溶出させるもので、 isocratic 溶出と呼ばれる。超臨界流体を移動相として 使用するときも、カラム出口の背圧制御バルブとポン プヘッド冷却装置が必要となる他は LC と同様な装置 が利用できる ( Fig.1 参照)。 


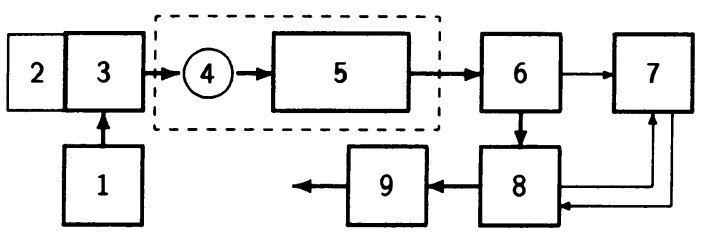

Fig.1. Experimental setup.

1. mobile phase reservoir(liquid $\mathrm{CO}_{2}$ or organic solvents), 2. pumphead cooling device, 3. pump, 4. six-port sample injection valve, 5 . column, 6 . UVdetector, 7. personal computer, 8. back pressure regulator, 9. flow-meter, dashbox $=$ column oven, thicklines $=$ mobile phase, thinlines $=$ electric signals

SFCでは、移動相として超臨界二酸化炭素、カラム として逆相液体クロマトグラフィーシリカゲル (ODS) カラムがよく利用される。超臨界二酸化炭素の利点は、 臨界温度が低く熱に不安定な物質の分離に有利である こと、無害であることなどがあげられる。ポリマー系 充填戍があまり使用されていないのは、超臨界二酸化 炭素中ではポリマーが可塑化されて劣化する可能性が あるからである。

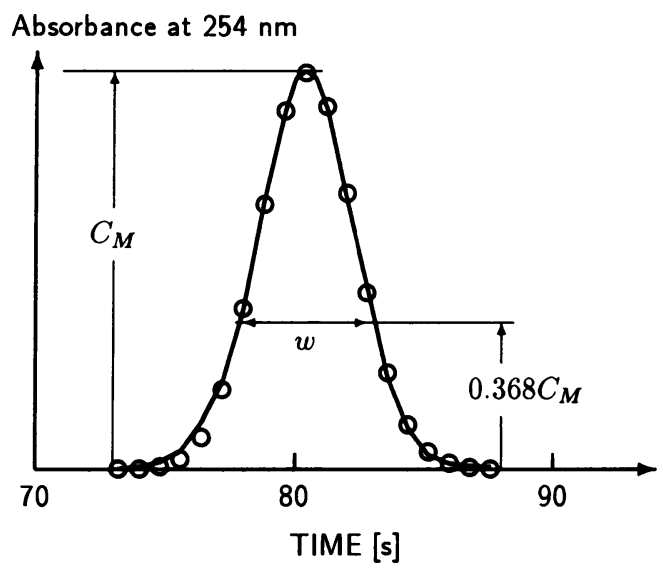

Fig.2. Typical experimental and calculated elution curves for SFC. column:reversed phase chromatography silica-based (ODS) column [ TSKgel ODS-80Ts (Tosoh), inside diameter $=4.6 \mathrm{~mm}$, length $15 \mathrm{~cm}$, pore size $8 \mathrm{~nm}$, particle diameter $\left.d_{p}=35 \mu \mathrm{m}\right]$, mobile phase: supercritical carbon dioxide $\left(T=40^{\circ} \mathrm{C}, p=10\right.$ $\mathrm{MPa})$, sample: $2-6$ dimethyl naphthalene $(10 \mu \mathrm{L}, 0.5$ $\mathrm{mg} / \mathrm{mL}$ ),$-=$ experimental, $\mathrm{O}=$ calculated (see ref. [11])
カラム性能は、パルス状に導入した試料のカラム出 ロでの応答曲線（溶出曲線、クロマトグラム）のピー ク位置と幅から求められる HETPにより評価される (Fig.2)。以下の解析手法の詳細は文献を参照された い $[1,2,7,8,9,10]$ 。
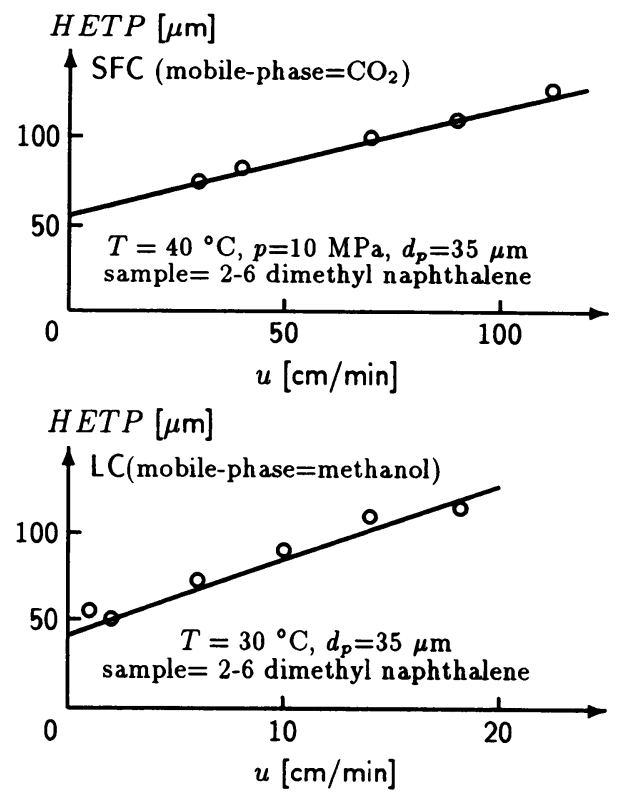

Fig.3 HETP vs. u.

$$
H E T P=Z\left(w / t_{R}\right)^{2} / 8=Z\left(W / t_{R}\right)^{2} / 16
$$

ここで、 $Z$ はカラム長さ、 $w$ は溶出曲線のピーク高さ の 0.368 倍の位置における幅、Wは溶出曲線のベース ラインにおける幅、 $t_{R}$ はピーク保持時間である（この 解析では、溶出曲線がガウス分布であることが暗黙に 仮定されている)。

分配係数 $K$ は $t_{R}$ から $(2)$ 式により決定される。

$$
K=\left[\left(t_{R} u / Z\right)-1\right] / H
$$

ここで、 $u$ は移動相線速度、 $H$ は固定相と移動相の体 積比である。試料の固定相への分配を表す $K$ は移動相 組成により変化する。また試料濃度に依存するときも あるが、(1) 式の HETPにより性能評価解析するとき には、Kが濃度に無関係で一定であることが必要条件 である。

溶出曲線を移動相線速度 $u$ の関数として测定し、 HETPを $u$ に対してプロットすると Fig.3のような結 果が得られる。HETP-u曲線は、次式により解析さ れる。

$$
H E T P=A+B / u+C u+D u
$$


(3) 式で右辺第一項は軸方向の混合抎散の寄与を表し $d_{p}$ の関数である。右辺第二項は分子拻散、第三項は固 定相（粒子内）拡散、第四項は粒子まわりの境膜物質 移動を表す。

広い実験条件結果の $H E T P$ と移動相線速度 $u$ を比 較するためには、以下の無次元式が便利である。

$$
h=A^{*}+B^{*} / \nu+C^{*} \nu+D^{*} \nu
$$

ここで、 $h=H E T P / d_{p}$ は換算 $H E T P, \nu=u d_{p} / D_{m}$ は換算速度である $\left(D_{m}=\right.$ 分子拡散係数 $)$ 。

低分子と高分子では操作範囲が異なり、高分子溶質 の LC 分離では $10<\nu<200 \sim 300$ 程度の範囲にあ り、第 1 項と第 3 項で表される直線となり、切片が軸方 向混合拡散の、傾きが固定相払散の寄与を表す。また、 切片から求められた $P e$ 数は $0.5 \sim 1.2$ 程度であり、固 定相抎散係数 $D_{s}$ は分子拡散係数 $D_{m}$ の $0.05 \sim 0.3$ 程 度に低下する [7-10]。

低分子の HPLC あるいは SFC では $\nu<20$ 以下 の領域で操作されることが多く、このような領域では $H E T P=2 \sim 10 d_{p}$ 程度である。比較的大きな粒子径 のカラムを用いることにより第 1 項と第 3 項で支配さ れる領域で実験を行なった結果の一例を Fig.3に示す。 この図より SFC の移動相線速度は LC の約 5 倍であ ること、しかしながら HETPの值はほほ同じ範囲に あることがわかる。この実験において SFC の移動相 線速度の上限は、実験精度の関係で保持時間が約 1 分 としており、移動相の条件により最大 $220 \mathrm{~cm} / \mathrm{min}$ 程 度まで実験を行っている。液系 (LC) の最大速度は圧 力損失の上限 $(30 \mathrm{MPa})$ で規定している。SFC が高速 で操作できるのは超臨界流体が低粘性であるので圧力 損失が低いからである。

Fig.3のデータを(4) 式で整理すると Fig.4のように なる。困には種々の移動相状態の SFC と LC、さらには 液体 $\mathrm{CO}_{2}$ を移動相としたときの結果も載せている。前 述の実験結果は、SFC, LC ともに $10<\nu<60$ の領域 となっている（実際の線速度では、LCでは $2<u<20$ $\mathrm{cm} / \mathrm{min}, \mathrm{SFC}$ では $30<u<220 \mathrm{~cm} / \mathrm{min}$ である)。図 から明らかなように移動相の状態によらず、ほほデー 夕は一本の直線で表すことができる。また異なる粒子 径のデー夕も無次元化することにより、ほぼ一つの曲 線で表すことができた。困には記載しなかったが naphthalene, benzothiophene, phenanthrene などの他の試 料の実験テータもほほ同様な結果となった。

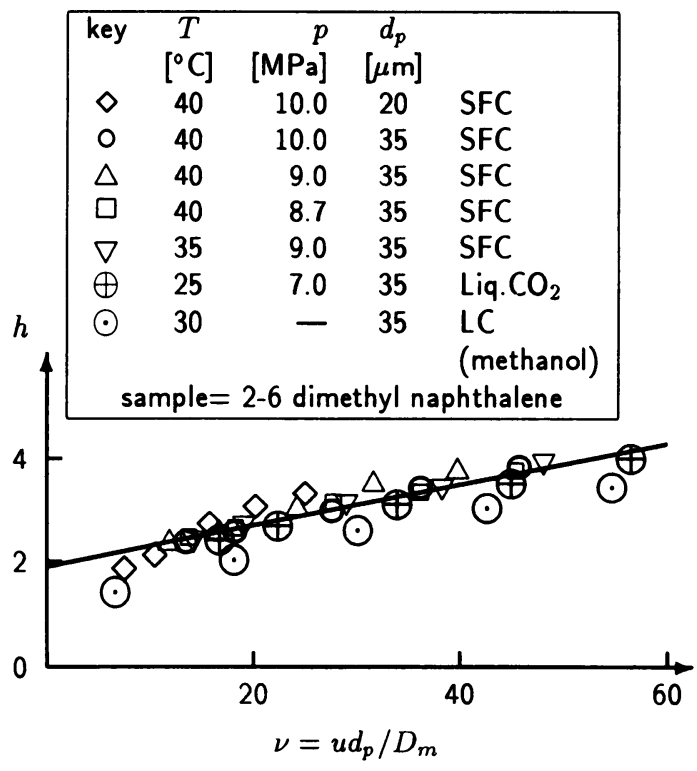

Fig.4 $h=H E T P / d_{p}$ vs. $\nu=u d_{p} / D_{m}$.

(3) あるいは (4) 式に基づいて実験結果より求めた $P e$ 数と $\gamma_{s}=D_{s} / D_{m}$ を Table 1 にまとめる。Pe は、 SFC,LC ともにほほ 1 1.5 程度で、SFC が特異である という結果ではない。 $\gamma_{s}$ は厳密には分配係数の関数と なるが [7]、ここでは $0.03 \sim 0.2$ 程度の值であり $\mathrm{SFC}$ の方が低い。この理由については今後検討したい。

Table 1. Values of Peclet number $P e$ and obstructive factor in the stationary phase $\gamma_{s}$

\begin{tabular}{lccl}
\hline sample & $\begin{array}{c}P e= \\
u d_{p} / D_{L}\end{array}$ & $\begin{array}{c}\gamma_{s}= \\
D_{s} / D_{m}\end{array}$ & $\begin{array}{l}\text { mobile } \\
\text { phase }\end{array}$ \\
\hline naphthalene & $1.3 \sim 1.6$ & $0.14 \sim 0.18$ & liquid $^{2)}$ \\
2-6-DMN 1) & $1.2 \sim 1.5$ & $0.10 \sim 0.20$ & \\
benzothiophene & $1.0 \sim 1.3$ & $0.16 \sim 0.21$ & \\
phenanthrene & $1.2 \sim 1.5$ & $0.16 \sim 0.18$ & \\
\hline naphthalene & $1.0 \sim 1.5$ & $0.03 \sim 0.06$ & super- \\
2-6-DMN & $1.1 \sim 1.5$ & $0.03 \sim 0.09$ & critical \\
benzothiophene & $0.8 \sim 1.5$ & $0.03 \sim 0.07$ & fluid $\left.^{3}\right)$ \\
phenanthrene & $1.0 \sim 1.2$ & $0.03 \sim 0.07$ & \\
\hline
\end{tabular}

1) 2-6-DMN $=2-6$-dimethyl naphthalene

2) methanol-water: mole fraction $0.51 \sim 1.0$, $T=303 \sim 323 \mathrm{~K}$

3) supercritical $\mathrm{CO}_{2}: p=8.5 \sim 15 \mathrm{MPa}$, $T=308 \sim 318 \mathrm{~K}$ 


\section{3. 分配係数}

分配係数 $K$ は、圧力 $(p)$ の增加あるいは温度 $(T)$ の 增加とともに減少する。液系では $K$ はモル分率と相関 されるが、超臨界流体系では $K$ と移動相密度 $\rho_{m}$ には よい相関が見られる（Fig.5）[2]。

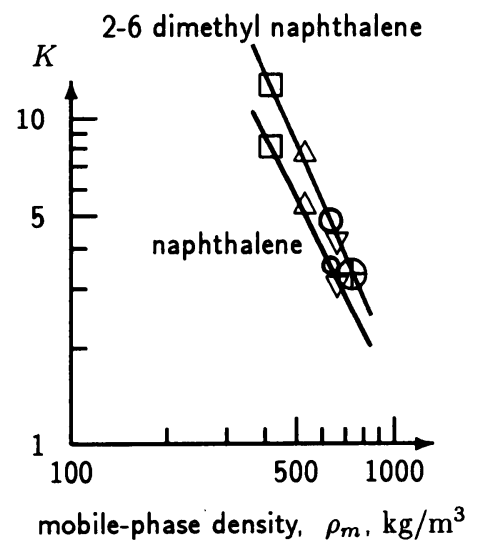

Fig.5 $K$ vs. $\rho_{m}$. The keys are the same in Fig.4.

\section{4. 圧力勾配溶出}

液系 (LC) では分配係数に強く影響する移動相組成 を時間的に変化させる溶出方法 (勾配溶出) が高度分 離手法として用いられる [7-9]。SFC では分配係数は 密度に依存するが、これは温度あるいは圧力を変化さ せることに対応する。どちらも、他成分（モティファイ アー）の添加とは異なり基本的には移動相そのものを 変えないので、回収後の画分に混入することがない。こ のことは LCにおける勾配溶出にくらべて利点となる。

ここでは圧力を直線的に変化させる圧力勾配溶出を 実験的に試みた。この場合、温度一定かつ入口での液 体二酸化炭素体積流量一定で行っているのでカラム内 での密度は時間とともに変化する。移動相線速度も従っ て時間とともに変化している。一定圧力（等圧）での 実験結果から得られたパラメーターのみを用いて計算 された溶出曲線は実験結果と良く一致し、圧力勾配溶 出の分離挙動が推定できることが示唆された。この計 算には密度の関数としての分配係数（Fig.5）を定式 化してモデル計算に組み込んでいる。計算には実験値 に fitting させる変数は含まれていない。また、文献 [14] で示しているように、 $N \gg 100$ ではどのモデルも
基本的には同じ溶出曲線を与えるので、ここでは最も 計算が容易な discontinuous-plate model を使用した。

5. 考察

ここまで述べたきたことに基づいて超臨界流体クロ マトクララフィー (SFC) の利点を考察してみる。

1. 移動相の粘度・密度に基づいて計算した無次元速 度で整理すると HETPは相の状態に無関係に整 理できる。すなわち軸方向混合拡散係数は超臨 界流体でも液体状態でもほほ同じ値である。ま た、固定相払散係数の分子抝散係数からの低下 率も超臨界状態、液体状態ともに同程度である

2. 分配係数は超臨界流体あるいは液体二酸化炭素 の移動相密度と良い相関が可能である。

3. したがって SFCでは液系の $5 \sim 10$ 倍の移動相 線速度でも液系と同様なカラム効率を得ること ができる。また、このような高速でも超臨界流 体の低粘性のため圧力損失は小さい。

ここでは主として試料負荷量が $H E T P$ と保持容量 $V_{R}$ に影響しないような低負荷量で実験を中心に解析 している。液体クロマトグラフィー (LC) の試料容量 の增加の影響は容易に推算できる $[1-4]$ 。一方、SFC における試料負荷量の影響の厳密な解析は複雑である。 本研究では試料を液状態で注入しているが、特に試料 容量を增したときは溶出曲線が歪む (leading) 傾向が ある。小容量で濃度を増加しても溶出曲線の変形は観 察されないので、試料の液体での注入に問題があると 考えられる。また、圧力勾配溶出では、試料負荷量を 等圧溶出にくらべて增加させることができた。これは、 圧力勾配溶出では最初分配係数が大きいので試料が力 ラム上部に一度吸着保持されるからであろう。この方 法を含めて高試料負荷量に適した方法の開発が望まれ る。工業プロセス LC の装置は既に開発改良が重ねら れており、希望通りの仕様の製品が入手できる。SFC では前述の試料注入装置のみならず試料回収装置など 今後も検討すべき課題が数多く残っている。これらに ついては、平田が詳細に解説している [6]。また、装 置全体についての概説もある [2-5]。

上記の理由により厳密な生産性の推算は現時点で不 可能であるが、試料容量が低く、その溶出曲線に対す る影響がほとんどない領域での SFC と LC との分離 性能の比較を簡単なモデルにより試みることにする。

最も簡単な分離の程度を表す尺度として $2 つ$ の溶出 曲線のピーク位置とピーク幅を用いた $R_{s}$ が利用され る [7-9]。 


$$
R_{s}=\frac{\left(t_{R, 2}-t_{R, 1}\right)}{\left[\left(W_{1}+W_{2}\right) / 2\right]}
$$

2 成分が等量であるとき、 $R_{s}=1.3$ でほほ完全分離 となる。いま、同じカラムを使用して低試料負荷量で $R_{s}=1.3$ となる移動相線速度 $u$ を計算する。(5) 式に (1)(2) 式を代入し整理すると、(6) 式となる [7-9]。

$$
R_{s}=\frac{H\left(K_{2}-K_{1}\right)}{4\left(1+H K_{1}\right)} \frac{\sqrt{Z}}{\sqrt{H E T P_{1}}}
$$

ここで、 $W_{2} \approx W_{1}$ と仮定している。(6) 式から明らか なように分離度は 2 成分の分配係数差に比例する。 LC ではメタノール 70\%、SFCでは密度 $\rho_{m}=600 \mathrm{~kg} / \mathrm{m}^{3}$ の ときに naphthalene と 2-6 dimethyl naphthalene の分 配係数差が大きい。この条件と $h-\nu$ の関係を (6) 式 に代入するとカラム長さ $Z=50 \mathrm{~cm}, d_{p}=100 \mu \mathrm{m}$ のと き、 $R_{s}=1.3$ となる $u$ は

$$
u_{S F C} / u_{L C}=3.3
$$

となる。すなわち SFC の分離時間は LC の約 $1 / 3$ と なる。この比較計算では、LC の分配係数差が SFC の 約 1.7 倍であるので、SFCにおいては分配係数差が小 さいことによる分離度の低下を㹡散係数の増加で補偵 していることになる。

\section{6. 結論と今後の展望}

超臨界流体クロマトグラフィーの分離特性について 液体クロマトグラフィーと比較しながら実験とモテル 計算により説明した。超臨界流体の高抎散性により高 性能分離が期待できるが、低溶解性により試料負荷量が 規定される傾向がある。また、液体クロマトクラフィー モデルを基に超臨界流体クロマトグラフィーの圧力勾 配溶出にも適用可能なシミュレーションモテルを構築 したが、今後はこのモテルに試料負荷量の影響を組み 込むことにより最適操作条件の推定方法の検討が必要 である。

実験については超臨界二酸化炭素への溶解度が比較 的高い低分子の分離機構は明らかとなったが、今後は 高度不飽和脂肪酸のような高分子量・低溶解度物質分 離特性の解析が望まれる。また分離性能あるいは最適 条件の推定のためには、分子拡散係数や溶解度などの 物性值の推算方法の開発 [16] も必要不可欠である。

\section{記号表}

$$
\begin{aligned}
& A=2 D_{L} / u(\mathrm{~cm}) \\
& A^{*}=2 D_{L} / u d_{p}=2 / P e(-)
\end{aligned}
$$



$B=2 \gamma_{m} D_{m}\left(\mathrm{~cm}^{2} / \mathrm{s}\right)$

$B^{*}=2 \gamma_{m}(-)$

$C=$ solute concentration in the mobile phase

$C=d_{p}^{2} R(1-R) /\left(30 D_{s}\right)$

$=d_{p}^{2} H K /\left[30 D_{s}(1+H K)^{2}\right]$

$=R(1-R) /\left(30 \gamma_{s}\right)$

$=H K /\left[30 \gamma_{s}(1+H K)^{2}\right](-)$

$C_{M}=$ peak maximum concentration

$C_{s}=$ solute concentration

in the stationary phase

$C_{0}=$ initial concentration

$D=d_{p} H K^{2} /\left[3 k_{F}(1+H K)^{2}\right]$

$D^{*}=D_{m} H K^{2} /\left[3 d_{p} k_{F}(1+H K)^{2}\right]$

$D_{L}=$ axial dispersion coefficient $\left(\mathrm{cm}^{2} / \mathrm{s}\right)$

$D_{m}=$ molecular diffusion coefficient $\left(\mathrm{cm}^{2} / \mathrm{s}\right)$

$D_{s}=$ effective stationary phase diffusivity $\left(\mathrm{cm}^{2} / \mathrm{s}\right)$

$d_{p}=$ particle diameter $(\mu \mathrm{m})$

$F=$ volumetric flow rate $(\mathrm{mL} / \mathrm{min})$

$H=(1-\epsilon) / \epsilon$

$H E T P=$ plate height $(\mathrm{cm})$

$h=H E T P / d_{p}=$ reduced plate height

$K=C_{s} / C=$ distribution coefficient

$k_{F}=$ mass transfer coefficient $(\mathrm{cm} / \mathrm{s})$

$N=$ total number of the theoretical plates

$P e=u d_{p} / D_{L}=$ axial Peclet number

$p=$ pressure $(\mathrm{MPa})$

$R=1 /(1+H K)$

$R_{s}=$ resolution

$=F /\left(A_{c} \epsilon\right)$

$T=$ temperature $\left(\mathrm{K}\right.$ or $\left.{ }^{\circ} \mathrm{C}\right)$

$t=$ time $(\mathrm{s})$

$t_{R}=$ peak retention time $(\mathrm{s})$

$V_{F}=$ sample feed volume $(\mathrm{mL})$

$V_{o}=V_{t} \epsilon$ column void volume $(\mathrm{mL})$

$V_{t}=A_{c} Z$ total column volume $(\mathrm{mL})$

$V_{R}=F t_{R}$, retention volume $(\mathrm{mL})$

$V_{s}=V_{t}-V o$,stationary phase volume $(\mathrm{mL})$

$W=$ baseline width of the elution curve (s)

$Z=$ column length $(\mathrm{cm})$ 
Greek

$\epsilon=$ column void fraction

$\gamma_{m}=$ tortousity factor in the mobile phase

$\gamma_{s}=D_{s} / D_{m}$

$\nu=u d_{p} / D_{m}=$ reduced velocity

$\rho_{m}=$ mobile phase density $\left(\mathrm{kg} / \mathrm{m}^{3}\right)$

\section{参考文献}

[1] G.Guiochon, S.G.Shirazi and A.M.Katti: Fundamentals of preparative and nonlinear chromatography, Academic Press, Boston, 1994

[2] M.Perrut: J.Chromatogra. A, 658 293-313 (1994) "Advances in supercritical fluid chromatographic processes"

[3] P.Jusforgues: Process scale liquid chromatography, Edited by G.Subramanian, VCH, Weinheim, 1995, Chap7, p.154-162, "Instrumental design and separation in large scale industrial supercritical fluid chromatography"

[4] C.D.Bevan and C.J.Mellish: Process scale liquid chromatography, Edited by G.Subramanian, VCH, Weinheim, 1995 Chap.8, p.163-191, "Scaling-up of supercritical fluid chromatography to large scale applications"

[5] K.Robards, P.R.Haddad and P.E.Jackson: Principles and practice of modern chromatographic methods, Academic Press, London, 1994, Chap.7, p.381-405, "Supercritical fluid chromatography"

[6] 平田幸夫: 超臨界流体の科学と技術、監修斎藤 正三郎、三共ビジネス、1996，4 章 5 節, "分析・ 分画プロセス”

[7] 山本修一: 食品工学基礎講座 第 8 巻「分別と 精製」，光琳，1991，第 4 章，pp.123-220， "吸着”
[8] 山本修一: 分離科学ハンドブック, 共立出版, 1993, 2.1, p.233-240, "クロマトグラフィーの基 礎理論”

[9] S.Yamamoto,,K.Nakanishi and R.Matsuno: Ion Exchange Chromatography of Proteins, Marcel Dekker,1988.

[10] S.Yamamoto, M.Nomura and Y.Sano: J.Chromatogr., 394, 363-367 (1987). "Factors affecting the relationship between the plate height and the linear mobile phase velocity in gel filtration chromatography of proteins"

[11] S.Yamamoto, M.Nomura and Y.Sano: J.Chromatogr., 512,77-87 (1990). "Predicting the performance of gel-filtration chromatogarphy of proteins"

[12] S.Yamamoto and Y.Sano: J.Chromatogr., 597, 173-179 (1992) "Short-cut method for predicting the productivity in affinity chromatography"

[13] S.Yamamoto and Y.Sano: Developments in Food Engineering, ed.by T.Yano,R.Matsuno and K.Nakamura, Chapman Hall,1994, p.838-839, "The performance of preparative supercritical-fluid chromatography of lipids and related materials"

[14] S.Yamamoto, T.Suehisa and Y.Sano: Chem.Eng.Commun., 119, 221-230 (1993)" Preparative separation of proteins by gradient- and stepwise-elutionchromatography"

[15] 山本修一: 平成 6 年科学研究費補助金（重点 領域研究 (1) 224 「超臨界流体」A03）研究 成果報告書、1995, p.109-118, "超臨界流体ク口 マトグラフィーによる最適分取条件の推定”

[16] 船造俊孝、若尾法昭:化学工学論文集, 21, 204-211 (1995), "高密度二酸化炭素中における 有機化合物の相互抬散係数への Rough Hard Sphere モテルの適用”

[ 1995 年 12 月 18 日受理］ 